\title{
Arquivos de Memória e História: Cartas da serra, de Eurico Nlves
}

\section{Grazyelle Reis dos santos}

Eurico Alves Boaventura (1909-1974), poeta, contista e ensaísta feirense, ficou mais conhecido na Bahia e no Brasil devido à sua atuação no grupo formado em torno da revista Arco \& Flexa, em fins da década de 1920, expressão do modernismo baiano no fastígio de sua agitação. Muito do que Eurico produziu foi publicado de maneira esparsa em periódicos da Bahia, de Alagoas e de Pernambuco, de 1926 a 1970, de modo que só após a sua morte foi editada parte significativa da sua produção, a maior parte ainda inéditas (OLIVIERI-GODET, 1999). Fidalgos e vaqueiros (1989), Poesia (1990) e A paisagem urbana e o homem (2007) vieram a lume a partir do empenho de Maria Eugênia Boaventura, sua filha, em editar parcela do seu arquivo literário, ressaltando a importância do escritor Eurico Alves não só para Feira de Santana seu lugar de nascimento, por ele aclamado em prosa e verso - mas também para a literatura baiana e brasileira. Rita Olivieri-Godet (ibid., p. 11) destaca que a edição tardia de obras do escritor dificultou "a divulgação e o reconhecimento crítico de uma produção intelectual estreitamente vinculada à sua região e ao seu tempo". Apesar disso, atualmente já existem estudos importantes sobre a sua vida e obra (ALVES, 1978, 1999; OLIVIERI-GODET, 1999; DÓREA, 1978, 1999, 2005; PEREIRA, 1999; SOARES, 2001, 2002, 2003), o que tem ampliado a sua fortuna crítica.

Tendo se graduado pela Faculdade de Direito da Bahia em 1934, em seu itinerário profissional Eurico atuou em diversas cidades do interior baiano a partir de 1935 e até fins dos anos 1960, quando se aposentou e retornou de vez à sua terra (DÓREA, 1999). Não obstante, mesmo que ao longo desses anos dedicados à magistratura tivesse que se ausentar de Feira de Santana, para onde regressava em tempos de férias principalmente, o escritor Eurico Alves a fez presente em muitas de suas criações literárias, em que costumava misturar registros de sua memória pessoal e dados sobre 
a história da sua cidade. Segundo Valter Soares (2003, p. 90-91), "Feira de Santana é referência central na escrita de Eurico [...] é a cidade-síntese, pois lugar onde tradição, memória e identidade se tocam e se entrelaçam, porque contexto a partir do qual Eurico exercita o seu pensar/sentir e tece a sua rede de significados". A respeito da relação de Eurico Alves com a sua cidade, Juraci Dórea acrescenta também que

Feira de Santana é compreensivelmente, na obra de Eurico Alves, tema essencial e recorrente. Primeiro, porque ele tinha pela terra natal uma paixão incontrolável, um amor sem medidas [...]. Segundo, por ser a Feira de Santana de Eurico Alves uma cidade idealizada, uma cidade que ele revela a partir de um processo de arqueologia sentimental, onde se mesclam realidade, memória e poesia (DÓREA apud SOARES, 2003, p. 90).

No jornal feirense que nasceu no mesmo ano que ele, a Folha do Norte, Eurico Alves publicou alguns de seus escritos nas décadas de 1930 e 1940. Já nas duas décadas seguintes seu nome raras vezes apareceu neste jornal (SANTOS, 2008). Vale salientar que há na Folha do Norte um volume copioso de publicações literárias (entre crônicas, contos, cartas e poemas) de escritores da cidade. Desde o ano em que o jornal surgiu, seções literárias apareceram em quase todas as suas edições, onde foram publicadas tanto criações de escritores locais, como de nacionais e, às vezes, de estrangeiros. Em geral, o jornal Folha do Norte se tornou para muitos escritores feirenses um lugar de participação e de reconhecimento social deles na vida cultural de Feira de Santana, conquanto a maioria fosse diletante ou bissexta neste ofício. Além disso, foi freqüentemente o único veículo mediante o qual muitos desses escritores puderam constituir suas redes de interlocução com os leitores.

Caso particular foi o do escritor Eurico Alves, um dos intelectuais mais renomados e prestigiados na sociedade feirense, desde o tempo em que ainda era estudante em Salvador e atuante no grupo de modernistas baianos liderados por Carlos Chiacchio (1884-1947), juntamente com Godofredo Filho' (1904-1992). Buscando expressar essa consideração, na ocasião do seu qüinquagésimo aniversário, Dival Pitombo (1916-1989) publicou em primeira página, na edição no 2607 da Folha do Norte, a crônica "Cincoentenário de um poeta", em seu preito. E diz:

Complexos são os fatores pelos quais uma vida se realiza integralmente em sua destinação, dentro dos limites impostos pelo meio, pela época e pelas circunstâncias oriundas do determinismo biológico. Mas se realiza sempre quando presidida por um espírito privilegiado e uma personalidade singular. A projeção e a fama que cavalgam 
certas mediocridades ilustres, comumente não correspondem à medida do mérito real, permitindo a criação de tipos, dos quais o Pacheco de Eça constitui o símbolo eterno. Entretanto, a recíproca esconde, muitas vezes, pela atitude consciente ou não de indiferença ou desencanto, valores admiráveis que somente a sensibilidade de alguns íntimos descobre e guarda a profunda impressão que lhes deixam.

Aí se enquadra perfeitamente o poeta Eurico Alves.

Afora a concepção determinista, manifesta em sua escrita, Dival Pitombo, que foi amigo muito próximo de Eurico Alves e, também, escritor e intelectual conceituado em Feira de Santana, evidencia nesta crônica o reconhecimento de Eurico para os que tiveram a ocasião de manter contato com a sua palavra ou com a sua presença. Pitombo lembra ainda em outros trechos que Eurico era magistrado, mas antes de tudo era poeta "no sentido profundo do vocábulo", que "vive e apreende realmente o flagrante da beleza em sua plenitude integral". Além da dedicação à poesia, Dival Pitombo ressalta o ineditismo dos trabalhos de natureza histórica e sociológica, para os quais o seu amigo Eurico realizou um profundo trabalho de investigação. E recorda "os tempos ousados da investida modernista onde o prazer supremo consistia em irritar a burrice reacionária”, testemunhando:

Quem o conheceu na juventude integrando o inquieto grupo de "Arco \& Flexa" na velha Salvador, formando a bateria de vanguarda no assalto à cidade do academicismo literário, bombardeada rijamente pela revolução modernista de vinte e dois, quem o conheceu extravagante e "blagueur", contando baladas de Verlaine dentro da noite misteriosa da Bahia "pour épater lê bourgeois", pode formar idéia de sua evolução intelectual e espiritual, comparando-lhe os versos de então com sua poesia atual: sonora, elástica, diáfana.

Até o fim da sua vida Eurico Alves foi um apaixonado incondicional pela sua terra, sempre atento ao seu movimento, às suas mudanças, aos seus problemas, aos perfis de sua gente, às suas necessidades, às suas novidades, acompanhou passo a passo a sua trajetória histórica e seus fatos corriqueiros quase como um jornalista, interpretando-os com o olhar curioso e analítico de historiador, sociólogo, antropólogo, memorialista e cidadão.

Em 1960, Eurico escreveu as suas Cartas da Serra ${ }^{2}$, sendo que as duas primeiras, de um total de quatro ${ }^{3}$, foram publicadas no jornal Folha do Norte, em 21 de maio e em 06 de julho daquele ano, respectivamente. Nestes escritos, o autor preenche de significados e carrega de desejos o momento histórico vivenciado por Feira de Santana, 
àquela época, em que o jornal exalava o ânimo de mudanças urbanas que recriavam a paisagem arquitetônica e social feirense, num ritmo mais célere, se comparado às décadas anteriores (SANTOS, 2008). Essas mudanças se faziam perceber na dilatação do espaço urbano, inclusive com a criação de novas instituições (escolares, culturais, jurídicas, religiosas, financeiras, de saúde, etc.), de novos bairros e espaços de lazer, ao tempo em que a população crescia depressa ${ }^{4}$. E necessariamente porque Feira de Santana havia sido tomada por esse impulso de mudanças urbanas, uma das primeiras preocupações de Eurico Alves, demonstrada, sobretudo, na segunda de suas Cartas da Serra, foi com a salvaguarda de memórias e de histórias do passado feirense, de quando o ambiente pastoril era ainda o seu cenário comum.

É curioso que o escritor tenha usado o título Cartas da Serra e também o pseudônimo Zé Fernandes, quando as publicou na Folha do Norte. Juraci Dórea Falcão (2005) percebe aí um diálogo intertextual com o romance $A$ Cidade e as Serras, de Eça de Queiroz (1901), no qual Zé Fernandes é a personagem com quem Eurico Alves mais se identifica. E explica:

Eurico Alves que chega ao sertão, na década de 30, não há dúvida, está mais próximo de Jacinto do que de Zé Fernandes [...]. Mas, com o correr dos anos, o escritor baiano termina por reencontrar suas raízes sertanejas, identificando-se mesmo é com a figura desse curioso personagem serrano, criado por Eça de Queiroz. Da mesma forma que Zé Fernandes, também Eurico Alves revela alguns tropeços e, às vezes, percebe-se que a ligação de ambos com o campo é forte. Com o campo e com a serra. No caso de Eurico Alves, com uma serra, em particular: a de São José das Itapororocas (p. 163-164).

A primeira das Cartas da Serra mostra desejos e expectativas de um intelectual profundamente ligado à sua terra e, com a mesma intensidade, preocupado com o seu futuro. Eurico Alves a inicia comentando sobre a figura de Arnold Silva, seu amigo, pela segunda vez nomeado prefeito de Feira de Santana, naquele ano de 1960, para quem emite esta carta-crônica. Ao longo do texto tece elogios ao seu interlocutor e, no terceiro parágrafo, faz uma descrição detalhada do dia da posse de Arnold Silva para intendente de Feira de Santana, em 1924, quando pela primeira vez este político assumiu o governo do município. Eurico recorre à sua memória relembrando a ocasião, quando tinha apenas 15 anos de idade, e os trajes usados por ele, por seu pai e pelos membros da sociedade que receberam Silva no salão do Conselho Municipal. Nem mesmo a botina Stella, calçado usado por Eurico Alves e por outros garotos da 
época, ficou esquecida. Ela fica lembrada pelo escritor como o calçado usado pelos meninos quando iam às posses, quando "era tão homogêneo e respeitável o Conselho Municipal". E continua: "eu, embora minúsculo de talhe, estava pronto para a festa, metido em calças curtas, de colete, cadeia de relógio atravessada no colete, em meio a tanta gente de fraque e chapéu de pelo".

Ao invés de iniciar a carta fazendo um balanço do governo passado de Silva, Eurico Alves preferiu descrever o momento fastuoso da sua primeira posse, cheio de expectativas, momento em que também foi proferido um discurso cheio de promessas. Chega a relatar que, na cerimônia, "cobertas de jóias, as senhoras imponentes sacudiam airosamente leques finíssimos, completando a festa. Tal um figurino inglês, falou Arnold Silva". Segundo Eurico Alves, o político "fez tudinho o que estava no discurso. E foi reeleito. De novo, os fraques vieram dar imponência a outra tarde de novo janeiro".

Tendo recorrido à sua memória da juventude para registrar os pormenores daquela movimentação, e tendo reforçado a inclinação de Arnold Silva para o cargo que acabara de assumir, Eurico deu seguimento ao seu texto tendo em vista o seu objetivo maior: falar de Feira de Santana, colocando em discussão sua paisagem. O escritor recorreu à sua memória e comparou dois tempos: a Feira de Santana da década de 1920 e a de 1960. Num primeiro momento, a paisagem rural era ainda marcante; num segundo, o processo de urbanização já havia traçado uma nova geografia, um novo desenho, um novo ritmo e uma nova sonoridade para a cidade:

Nesse tempo [década de 1920] a Feira de Santana não passava de agradável alegoria de sutil poema de Francis Jammes. Só o ABC amplo e comprido como uma promessa de candidato a prefeito atualmente, entupido de chácaras e mais chácaras, valia como um descanso para os olhos. Lá no alto, do outro lado da cidade, o Alto do Cruzeiro abençoava a cidade. Mudaram-se os tempos. Já Feira de Santana de hoje é uma sugestiva ilustração de nervoso verso de Émile Verhaeren, ou a reticência de um trecho de Toda América, de Ronald de Carvalho. Dinamismo, vida nova, movimento e movimento. Nunca se poderá dizê-la "Cidade do Silêncio e da Melancolia". Foi-se esse tempo... Carros, autocaminhões, ônibus sacolejando a paisagem, a grita de buzinas vigorosas, alto-falantes desmentem essa legenda. Que coisa diferente!...

Eurico Alves deixa claro nesse trecho da sua carta-crônica as diferenças que saltam aos olhos entre uma época e outra. $\mathrm{O}$ importante registro da sua memória funciona como testemunho e, por mais que retrate duas temporalidades, Eurico evidencia o desejo de não romper com o fio histórico que as une, mesmo estando cons- 
ciente da ruptura paulatina com o passado, com o elã da urbanização em sua cidade. À época em que criou as Cartas da Serra, muita coisa em Feira de Santana era novidade: a paisagem urbana, os costumes, os valores, a política. Transitando pelo passado, o autor recordou a movimentação de outrora, as sensações, os sentimentos, o humor, os vestígios, os cenários, narrando o que o tempo não pôde corroer na sua memória afetiva. Ou seja, diante da impossibilidade de reviver, o escritor mergulhou na sua percepção individual e deixou aflorar emoções misturadas aos fatos. A respeito da relação entre a memória e a história, o historiador Pierre Nora (1984, p. 9) observa:

A memória é a vida, sempre carregada por grupos vivos e, nesse sentido, ela está em permanente evolução, aberta à dialética da lembrança e do esquecimento, inconsciente de suas deformações sucessivas, vulnerável a todos os usos e manipulações, susceptível de longas e de repentinas revitalizações [...] é um fenômeno sempre atual, um elo vivido no eterno presente [...] Porque afetiva e mágica, a memória não se acomoda a detalhes que a confortam, ela se alimenta de lembranças vagas, telescópicas, globais ou flutuantes, particulares ou simbólicas, sensível a todas as transferências, cenas, censura ou projeções.

Eurico Alves faz o percurso pendular do presente para o passado, para o presente outra vez, principalmente porque é motivado pelo pretexto da sua crônica: a reeleição de Arnold Silva para prefeito de Feira de Santana, em 1960. Fez esse movimento justamente porque quis estabelecer um confronto entre as diferentes temporalidades, que faz sentido diante das tantas descontinuidades do passado no presente. Um presente, aliás, que traz para o político Arnold Silva novos desafios, afinal, é outra a cidade. Diz Eurico:

Arnold Silva volta agora em outro ambiente. Tão diferente... Já não se vê um fraque sisudo na sua posse, já não se vende mais a garbosa botina Stella alegremente rangendo, para a meninada bem apresentada. Mas Arnold volta sempre inspirado pela legenda gloriosa do nosso passado.

Ainda que a cerimônia da segunda posse de Arnold Silva não tenha sido tão pomposa como a primeira, mais importava a Eurico Alves o fato de ser esse seu amigo um intelectual que alimentava, como ele, profundo interesse pela preservação das memórias do passado de Feira de Santana. E foi especialmente porque ambos comungavam de igual interesse que a primeira das Cartas da Serra, endereçada a mais alta autoridade política do município, conquanto tenha sido aberta à sociedade, por 
meio da Folha do Norte, visou tornar pública a preocupação que mais inquietava o escritor: impedir que Feira de Santana tivesse sua história olvidada ou escamoteada pela falta de zelo com os restos do passado que continuamente iam se dissipando pela força do tempo e do homem.

Arnold Silva lançou na Folha do Norte, em 1923, a coluna "Crônica feirense" (onde, a princípio, assinava com o pseudônimo Gil Moncorvo), depois intitulada "Vida feirense”, excluída em 1952 (MORAIS,1998). Nessa seção do jornal ele organizou registros relativos à história de Feira de Santana, anotando eventos e datas marcantes e apresentando dados aos quais teve acesso principalmente em arquivos de Feira de Santana e de Salvador. A respeito desta coluna, Ana Angélica Morais ( p. 34) afirma:

Arnold Silva, foi, no jornal, além de fundador, diretor durante muitos anos (19231952), jornalista e escritor de crônicas e contos. Durante esse período, escreveu cerca de 250 crônicas-relatos, publicadas semanalmente. Ele dedicou uma boa parte de sua vida (três décadas) à pesquisa sobre o município e a cidade de Feira de Santana, visitando, cotidianamente, os arquivos públicos e particulares, as bibliotecas municipal e nacional, os grêmios literários, as filarmônicas, cartórios, batistérios e demais órgãos públicos de Feira de Santana e de outras capitais. Além dessa coluna, ele também escrevia editoriais e contos.

Em Cartas da Serra I Eurico Alves apresentou uma inquietação particular com a beleza, a estética da cidade. Ressalta neste documento que

Feira de Santana não é só a balança de gado, nem a roça de algodão, nem o trapiche de fumo. Nem é só a Mesa de Rendas. Feira de Santana é mais que isto tudo.

Embeleza-se a cidade. Seria melhor que se dissesse quase se renova a cidade vigorosamente. Foi sempre bonita desde a nascença. Mas vez ou outra, há um cochilo na elegância da cidade. Nem sempre a beleza, nem sempre o sentido de estesia estão presentes nas construções que se levantam nas suas ruas novas. Mal que não é só nosso, diga-se logo. Nas outras cidades da Bahia, na sua própria capital, estão sendo construídos monstrengos de cimento, a que se dá o pomposo nome de casa. Falta-nos o gosto, falta-nos a noção de elegância para tais construções. O que se registra é o grito do arrivista, no mais das vezes, propalando o custo dos pisos, dos sanitários (e como falam em sanitários! O saudoso José Valadares estava projetando analisar esta preocupação pelo serviço sanitário luxuoso de certa classe de gente), o preço das cortinas, de tudo. Parece mais uma exposição de produtos mercantis do que uma vivenda.

A crônica de Eurico Alves apresenta uma movimentação temporal, ao passo em que o escritor inscreve as mudanças que se imprimem na paisagem urbana feirense. 
Autêntico defensor da sua terra, o autor admite que a proeminência de Feira de Santana para a região onde se fixa extrapola as suas imagens e funções usuais, como a "balança de gado" ou a "Mesa de Rendas". No entanto, embora admire a beleza da cidade, ele preocupa-se com o perigo de que a cidade se torne semelhante a tantas outras, seguindo padrões arquitetônicos e decorativos, ornamentais, estilos de moda que lhe tire a aparência singular e distintiva do seu ambiente natural e urbano, o que é uma constatação do presente vivido e sentido pelo escritor. Não obstante, este perigo com que o autor convive se aguça à medida que a cidade se expande e ele "ressente-se de um processo de urbanização que desfigura a cidade, fazendo-a perder a sua beleza original, seu sentido de estesia" (SOARES, op. cit., p. 95). Acerca das mudanças na aparência urbana de Feira de Santana, de que fala Eurico Alves em Cartas da Serra I, Valter Soares (p. 95-96) diz que

No gesto de protesto frente à modificação da paisagem urbana, delineia-se sobretudo o avanço de uma cidade cuja nova fisionomia vai se construindo sobre os escombros de uma velha ordem e seus símbolos. Alterações que vão lançando para os subterrâneos da história antigas tradições e colocando em risco uma memória e uma identidade tecidas em torno do lugar.

Em Cartas da Serra I, o escritor feirense mostra-se saudoso de um espaço que nunca mais poderá ser o mesmo de antigamente, só possível de ser evocado pela memória ou por meio de fragmentos ainda conservados do passado. É a crescente distância do presente para com o passado que provoca no escritor um sentimento de perda, de ausência, do que seu discurso é um novo vestígio, indício, trilha:

Onde as chácaras, as solenes chácaras do ABC? Quem, nesta cidade, contar com duas quinzenas de vida, pode bem sentir saudades do carinho das velhas frondes amigas, que nos acolhiam serenamente nas vibráteis manhãs de verão. Estão longe estas franças amplíssimas. Apenas na saudade dos que viveram aqui até o início da quarta década do século.

Pondo em confronto história e memória, presente e passado, modernidade e tradição, Eurico identifica as mudanças que alteram definitivamente a paisagem urbana e o homem feirense, conquanto mostre a expectativa de preservar tudo quanto for possível do passado, para não deixar esquecidos ou abolidos dados sobre a história e a cultura da sua terra. Constata que Feira de Santana urbanizada "ficará uma cidade de tipo longelino, antropologicamente falando". E verifica o que ainda resta no pre- 
sente da cidade de outrora: o Parque Santana, a Praça Padre Ovídeo, um pedaço da Praça Fróes da Mota, além de:

uns restos melancólicos do velho jardim Bernardino Bahia. Só. E isto na parte velha da cidade. No trecho que surge, a ordem dos levantadores de casas é para destruir toda árvore arrogante que se encontre. Pomares, chácaras lá se vão de roldão. Pena que não haja uma edição popular das palavras de Ruskin. É pena...

O discurso do escritor é quase um lamento pela perda de referenciais que sucumbem com o processo de urbanização em Feira de Santana. O espólio dos lugares que ainda resistem à força avassaladora desse processo define "lugares de memória", na fala de Eurico Alves. Segundo Pierre Nora (1984, p. 13) os lugares de memória existem porque não há memória espontânea. São, por exemplo, arquivos, museus, bibliotecas, cemitérios, coleções, festas de aniversários, tratados, processos verbais, monumentos, santuários, associações, que "são marcos testemunhas de outra era, ilusões da eternidade. Entretanto, uma sociedade que não reconhece sua origem, seu processo ontológico de constituição, perde o fio da trajetória histórica". Nora afirma também que "os lugares de memória são, antes de tudo, restos" (p. 12). Em Cartas da Serra I, o que escritor Eurico Alves enumera como lugares de memória são, de fato, restos, o que ainda subsiste aos efeitos destrutivos das construções hodiernas. Este escritor chama a atenção para esses lugares pelo que significaram para a constituição da sociedade feirense, já que existe o perigo do que Nora (p. 13) chama de "desritualização de nosso mundo":

O que secreta, veste, estabelece, constrói, decreta, mantém pelo artifício e pela vontade uma coletividade fundamentalmente envolvida em sua transformação e sua renovação. Valorizando, por natureza, mais o novo do que o antigo, mais o jovem do que o velho, mais o futuro do que o passado.

Para Eurico Alves, o perigo quiçá esteja precisamente na valorização do presente, do novo, do progresso e, ao mesmo tempo, na depreciação do antigo. O escritor lamenta o aniquilamento do patrimônio cultural, levado a efeito enquanto Feira de Santana ia vivendo um processo vagaroso de urbanização em fins do século XIX e, mais rápido, nas primeiras décadas do século XX. Na impossibilidade de recobrar esse patrimônio, Eurico Alves faz um apelo a Arnold Silva, que é o de tomar medidas necessárias para salvaguardar o que ainda se salva na fisionomia urbana da antiga Santana da Feira ${ }^{5}$ e de valorizar a natureza da terra, como alternativa para realçar o colorido próprio da cidade. Diz Eurico Alves: 
A prefeitura prestaria um grande benefício ao povo se aproveitasse o avanço das casas e fizesse o seu avanço verde. No largo da nova estação da Leste, há alegre arremedo de jardim. Boa sugestão. Ali, vestígios do mato primitivo. Aproveitaria a prefeitura as plantas mais rústicas e mais decorativas e teria semeado recantos agradáveis aos olhos. Não é preciso apelar-se para a sensibilidade decorativa de BURLE MARX. E até se sentiriam bem alecrins, licuris, mandacarus, bromélias, sapateiras, gravatás. Porque se apelar para importados gladíolas, para antúrios, quando, a preço módico, se nos oferecem plantas belíssimas e de magnífico efeito decorativo? Imbés, gravatás... A flor-deSão-João seria ótima para os nossos recantos. Pelo menos, durante a quadra que vai de maio a setembro, teríamos as praças iluminadas de flores amarelas, oiro em cachos, em pingentes, caído perdulariamente sob os nossos passos. E, como recorda o velho DURÃO, no seu poema Caramuru,

Dando a ver por diante, e nas espaldas,

Cachos de ouro com verdes esmeraldas,

A flor-de-São-João alegraria a paisagem modernizada. O rubro dos cactos, a grita do flamboyant, o ouro da flor-de-São-João e o verde da folharia... E sem pedir tudo isto, regras e regras. Bastava-lhes a chuvarada do inverno, a benção temporã das trovoadas e tudo seria uma festa para a nossa sensibilidade.

A preocupação ecológica de Eurico Alves é parte do mesmo fito de rejeitar a proposta de edificação da cidade, aplacando, em compensação, sua feição mais genuína, explicitada até na vida que brota da sua natureza característica. Eurico teme que Feira de Santana se torne similar a tantas outras cidades que avançam ao ritmo do progresso, e, em vista disso, rejeita os ensaios de homogeneização da sua aparência. Como opção propõe que a sua paisagem seja enfeitada com plantas comuns da região. Quer singularizar o espaço, não para torná-lo exótico, mas sim para que, na sua aparência, mostre a sua face própria, o que é estreme, original do lugar. E ainda antecipa a reação daqueles que chegariam à cidade e notariam a ornamentação por ele sugerida:

E nós tabaréus, quando chegássemos à cidade civilizada e vendo que ela não anatematizaria a nossa lembrança, o prestígio das nossas plantas, ficaríamos tão contentes que iríamos cavar eleitores, fabricar candidatos a eleitores para aumentar o prestígio político do município.

A cidade se inscreve na sua fala como desejo, anseio, expectativa. Note-se que a sua preocupação não é apenas cultural, mas também política. Eurico indica um potencial a ser explorado que, segundo ele, aumentaria o prestígio do município. Aí se tem um embate entre cidade real e cidade do desejo, a concreta e a imaginada. O texto de Eurico Alves é, assim, tanto campo de experiência como horizonte de expectativa. 
Todo texto é uma rede de resistência (KRAMER, 1992) e é preciso respeitar todas as suas vozes e perceber que o campo que se pretende dominar sempre ultrapassa as estruturas explicativas que o definem. Perceber também que na leitura de textos e contextos históricos é importante reconhecer a complexidade de sua construção e a possibilidade de novos tipos de escrita sobre a mesma abordagem. É impossível reduzir o passado a uma ordem. Mas na linguagem escrita o passado se ordena conforme a visão e o lugar social de quem escreve. "A literatura sugere formas alternativas de conhecer e descrever o mundo e usa a linguagem imaginativa para representar as ambíguas e imbricantes categorias da vida, do pensamento, das palavras e da experiência" (op. cit., p. 158).

Em Cartas da Serra I, Eurico Alves apresentou uma percepção particular sobre Feira de Santana, em que identifica seus espaços de circulação social e de habitação, bem como os usos feitos desses espaços, no passado e no presente. Eurico reforça seu desejo de manter a aparência sertaneja da cidade, que não se altere a sua plasticidade sem que se atente para o que há de mais característico na cultura e na natureza local. Com esta intenção, escreve, por fim, a Arnold Silva:

Amigo Arnold Silva, você que lê a crítica dirigida aos que procuram imitar costumes de países e terras diferentes, que sabe como é ridículo o esnobismo de muita gente, faça a nossa paisagem permanecer sertaneja. Bem sertaneja, emoldurando os suntuosos arranha-céus, coisa que se encontra em todo canto, desde os que encantaram a Paul Morand, até os da nossa Capital. Com os nossos parques, as nossas plantas matutas, os visitantes terão algo que ver em aqui chegando. Está de acordo?

Seu admirador.

Conforme Michel Foucault (1966, p. 64), “o poeta é aquele que, por sob as diferenças nomeadas e cotidianamente previstas, reencontra os parentescos subterrâneos das coisas, suas similitudes dispersadas". Assim é o poeta Eurico Alves, ilustrando o território sentimental da sua existência em suas Cartas da Serra. O escritor fala de um lugar que lhe é familiar, a sua cidade, mostra intimidade com as coisas, com o aspecto e a dinâmica do espaço urbano feirense, que é o seu lugar. Em relação ao posicionamento de Eurico frente às mudanças urbanas em Feira de Santana, Juraci Dórea (2005, p. 166) afirma:

O esforço crítico de Eurico Alves, diante das mudanças urbanas de Feira de Santana, é de censura e apreensão, evidentemente, mas não traz o tom passadista. Ao contrário, o tom de seu discurso remete a certas questões ambientais que também na atualidade atormentam os moradores das cidades em crescimento. 
Juraci Dórea percebe que a preocupação de Eurico Alves com a preservação da memória sertaneja remete, no plano nacional, a iniciativas semelhantes, desenvolvidas por alguns expoentes do modernismo. Eurico fez o percurso de ida e vinda ao passado histórico da cidade para apreender as diferentes cenas que marcaram o seu olhar sobre o arquivo visível e sensível de Feira de Santana. Mostra a mobilidade e a dialética da história, que vive a constante relação entre presente e passado, em suas variadas dimensões e tensões. Ele quer reconciliar a paisagem da cidade com a sua natureza sertaneja. Ainda que o plural a habite, que Feira de Santana seja a cidade do encontro de diferentes, ao menos sua natureza lhe assegura um aspecto irrefutável: é sertão, sertaneja por essência. E no entender de Eurico Alves isso bem que poderia ser explorado em lugar de maquiá-la com os mesmos objetos, com o mesmo gosto que tornam tantas cidades semelhantes em seu aspecto exterior.

O mote da Carta da Serra II vem de mais outra preocupação de Eurico Alves: onde guardar os vestígios, os documentos do passado feirense. Nesta carta, Feira de Santana continua sendo o centro das atenções do escritor. Na primeira carta, Eurico Alves atentou para a aparência da cidade, dando palpites sobre a renovação de sua paisagem, e assinalou os espaços antigos ainda preservados, que mostram para os feirenses fragmentos do passado, da história, de uma ordem que se estabeleceu na cidade em sua estrutura concreta, no traçado de suas ruas, nas suas praças, nos seus prédios que guardam em suas marcas envelhecidas aspectos da cidade de outrora. Esse patrimônio é documento, é indício, e Eurico Alves tem a consciência disso. Todavia, também lança o seu olhar para outros tipos de documentos, de marcas, de testemunhos históricos. A sua maior preocupação é com o perigo que se apresenta, com o passar do tempo, de corrosão, de desgaste, de perda dos vestígios do passado histórico feirense. Por isso, a segunda das Cartas da Serra funciona também como denúncia do descaso das autoridades locais em relação à organização de arquivos, museus e bibliotecas em Feira de Santana.

Em Cartas da Serra II, espécie de carta aberta à população local, Eurico não analisa a cidade em si, mas a necessidade de criação de lugares de preservação da sua história e da sua memória. Numa atitude preocupada, o poeta faz um apelo à sociedade feirense para que compreenda os riscos de se olvidar ou de se escamotear o passado da cidade. A criação de arquivos e de museus, nesse caso, seria a solução premente para minorar os efeitos do tempo, que paulatinamente deteriora vestígios de outras épocas. O feirense, que nesse momento experimenta os abalos das mudanças modernizadoras, tornando-se um sujeito cada vez mais fragmentado pela perda de 
referenciais fixos com os quais estabelecia uma relação de identidade, deveria ter no arquivo e no museu a presença de indícios do passado que, mesmo fracionado, transmite a ele imagens dos primórdios desta sociedade. Assim, diz Eurico:

Toda gente espalha por aí a fora que o sertão é coisa vazia. Vazia como uma auréola decorativa. E a que envolve a nossa paisagem, para muita gente, está cheia apenas de sol. Sol e aboio. E, se assim fosse, isto seria pouco? E não é assim, todavia, todos o sabem. O que nos falta é exibir a prova do que se afirma, por exemplo, de que fizemos largo capítulo da história baiana. Isto. E a prova está aí. Basta que se vá ao arquivo público e se leia o material, a documentação da vida pretérita sertaneja.

Aqui mesmo, contamos com farto material documentário. Está, porém, criminosamente largado como um montão de estrume de gado, na malhada. Se se chegar a uma saleta de fundo, no palácio municipal, depois do salão do júri, encontraremos um corpo-de-delito da nossa incúria, do nosso crime. Empilhados, como coisa sem préstimo, centenas de processos estão sendo danificados pelo tempo. Criminosamente ali ficam.

Nesta carta Eurico acusa o desprezo com que são tratados documentos e monumentos que figuram o passado feirense. Critica a falta de uma organização sistematizada de todo esse material num lugar destinado a este fim. O perigo do esquecimento coloca o poeta em alerta, o impele a tomar um posicionamento, a chamar a atenção para essa falta de cuidados que pode ter como decorrência um distanciamento cada vez maior dos feirenses em relação ao passado da cidade, aos seus objetos, à sua cultura, aos seus símbolos e, de um modo geral, ao percurso da história feirense. $\mathrm{O}$ texto de Eurico Alves transmite o posicionamento político de um cidadão atento às mudanças que transfiguram a cidade e que tendem a enterrar vestígios e memórias de outras épocas. O poeta deseja perceber um sentido de continuidade, a afirmação das raízes sertanejas da cidade, para que os feirenses reconheçam um passado comum. É a ligação entre o passado e o presente o objetivo maior do escritor.

Eurico Alves, em Cartas da Serra II traz um olhar sobre Feira de Santana em 1960 e sobre como os feirenses vivenciam sua própria historicidade, nesse momento. Tratando do novo tempo e de sujeitos também novos, embora em crise, abalados com as mudanças que redesenham concreta e simbolicamente a cidade, Eurico transmite a necessidade de esses sujeitos não só buscarem se definir identitariamente, mas se definir valorizando os elementos do lugar, a natureza, os costumes, os objetos, as histórias e as memórias, sendo importante a criação e a manutenção de vínculos com o passado. O olhar de Eurico Alves sobre Feira de Santana é um olhar individual, 
comprometido pela forte relação que mantém com o lugar e com o desejo de que nele convivam sem maiores conflitos tradição e modernidade. A sociedade feirense, como qualquer outra sociedade, também vivencia relações antagônicas e os elementos de identificação do espaço são múltiplos e inclusive diferentes. Para Eurico, o essencial é que todos os cidadãos feirenses tenham acesso aos fragmentos do passado, compartilhem de um mesmo sentimento com respeito às memórias e histórias da cidade e estabeleçam, deste modo, laços de pertencimento. E assim continua:

Vamos ver se se consegue o Arquivo da Feira de Sant'Anna? E do arquivo se iria adiante. E porque não um Museu Municipal? O ambiente é rico de elementos que dariam para se compor vistoso museu. De início, lentamente, é verdade.

$[\ldots]$

Pobres tabaréus... Tabaréus uma conversa. Gente fidalga e formidável, nobreza áspera como espinho de mandacaru e que deu ao Estado nomes de realce. Encourados de Pedrão, Maria Quitéria, o Periquitão, o maior poeta das Américas, cuja voz tem ressonância de tempestades e clarões de alvoradas - CASTRO ALVES, da gente lá de Brumado. CASTRO ALVES guardava mais o jeito de tabaréu dos parentes maternos do que a etiqueta dos parentes paternos.

O sertão necessita de dar cor de si e exige o culto da sua gente, a história de seu passado. E aqui, na nossa cidade do planalto, teria a gente meios de começar a escrever esta história.

Onde um documento, onde uma fotografia, onde uma relíquia que lembram Maria Quitéria? Onde uma coisa concreta que assegura a recordação de uma das mais fortes vozes oratórias do Brasil, o grande pregador LACERDA?.

$[\ldots]$

E pouca gente sabe que, encanecido, solitário, perto daqui, está abandonado um velho canhão da Sabinada. Vamos carregar processionalmente esta relíquia para uma praça da cidade, ou para um jardim escolar? [...] Onde se encontra a farda, ou um retrato do capitão Manoel Alves de São Boaventura, aparentado com os velhos troncos dos Alves de São Boaventura daqui, e de Cachoeira, revolucionário também da Sabinada, preso, processado, julgado, porque sonhou a liberdade da sua terra? [...] E isto não é história por acaso? História no duro. História de verdade.

O autor propõe e justifica a criação de "lugares de memória", a reunião de vestígios, a reconciliação com o passado, a importância que deve ser dada aos heróis locais. Segundo ele, a sociedade feirense precisa presenciar esta lembrança, entender como o espaço da cidade fora experimentado em suas primeiras décadas de existência. Nascida como comunidade sertaneja e pastoril, onde a figura do vaqueiro e do tabaréu foram suas expressões típicas, para Eurico Alves Feira de Santana necessita- 
va de um espaço para o resguardo de utensílios do passado, com imagens em que possam se reconhecer neste tempo e afirmar suas origens para as gerações vindouras.

O lugar social de fala de Eurico interfere na seleção destas imagens. Fidalgo oriundo da casa-de-fazenda, ele busca analisar as relações e as tensões sociais tendo como parâmetro seu lugar de nascimento (SOARES, 2003). Seu discurso se aproxima do de uma história oficial que contempla os nomes de pessoas que se notabilizaram nesta sociedade por terem vencido lutas políticas, causas locais, ou que tiveram participação visibilizada na construção desta cidade por terem ocupado postos de destaque na sociedade. Deste modo, esta reconstrução do passado fica comprometida por seu olhar subjetivo. Eurico Alves também atenta para os documentos tidos como oficiais, como cartas e discursos, títulos, escrituras, mas também para outros tipos de documentos como vestuário, mobiliário, objetos de uso doméstico, fotografias e relíquias, o que amplia o leque de possibilidades através da qual a antiga sociedade é possível de ser notada e investigada.

$\mathrm{O}$ escritor reconhece os conflitos e tensões sociais que assinalam a história urbana e social feirense, sobretudo no período em que escreve suas Cartas da Serra, quando Feira de Santana havia se convertido em outra cidade, bem diferente de como era no início do século XX. Contudo, seu conflito pessoal é o que notabiliza a narrativa, bem como sua preocupação em mobilizar políticos, intelectuais e a sociedade como um todo para resguardar fragmentos da Feira de Santana antiga, estilhaços do passado que, mesmo representando uma imagem imperfeita do que antes fora "a cidade do silêncio e da melancolia", conseguiam recompor e dar visibilidade a símbolos culturais dos tempos idos, aproximando o feirense da história de sua própria terra. Essa preocupação era tão iminente para o escritor porque havia a ameaça de se perder para sempre, pela ação corrosiva do tempo ou pelo descuido do homem, traços do passado que resistiram a esses dois principais agentes de sua amortização. Eurico diz ainda que:

Um museu e a Feira de Sant'Anna estaria completa. Certa feita, numa visita que fiz a um amigo bacharel e estudioso do passado feirense, durante as férias, na sua fazenda, vi o carinho com que ali se cultua o passado de Feira de Sant'Anna e do sertão todo. Guarda ele um museu. Não somente de arqueologia indígena, como também da vida sertaneja. Vi ali muito retrato de gente do século passado. Vi muita obra de santeiro daqui. Leques, berloques, jornais, postais de boas festas, louça, mobiliário. Museu particular. E que custa a prefeitura organizar um museu da família maior, a comunidade? Se este meu amigo guarda documentos da sua família, como formais de partilha, escrituras 
de escravos, títulos de crédito, de eleitores do início da República, nós os da coletividade poderemos guardar toda a história da nossa região. Vamos tentar?

Para Eurico Alves é fundamental a necessidade de criação de espaços cômodos para conservação e acúmulo do patrimônio histórico, cultural e memorialístico da cidade de Feira de Santana, patrimônio este que engloba todo indício que testemunhe sobre fatos, cenas, hábitos, valores, rotinas, dramas e desejos outrora comuns. Os feirenses, que também participam da idéia de cidade, estariam, deste modo, mais próximos ou mais ligados à história local ao ter acesso às inúmeras fontes que dão a entender processos do seu passado.

O autor das Cartas da Serra ressalta nestes escritos imagens do passado feirense que, para ele, no tempo da sua escrita, eram mais vibráteis, mais intensas, e, assim, atribui significados e constrói identidades sobre a cidade, enfatizando a cultura sertaneja, como a sua expressão mais singular. Sobre o processo de construção de idéias sobre o espaço urbano, Albuquerque Jr., (1999) salienta que o espaço é em si resultado de práticas discursivas e não-discursivas, inseridas no campo de forças de poder e de saber, que constroem determinados estereótipos do lugar, razão pela qual integram o terreno instável das identidades, criações eminentemente históricas.

O ensejo de criação das Cartas da Serra de Eurico Alves vem da inquietação subjetiva que acomete o escritor, posto que, tendo nascido e vivido durante a sua infância e adolescência em um local com aparência ainda rural, como o era Feira de Santana nas primeiras décadas do século XX, onde "o ABC amplo e comprido [...] entupido de chácaras e mais chácaras, valia como um descanso para os olhos", as mudanças advindas com o processo de urbanização acabam por colocá-lo em uma crise pessoal, já que se identificava profundamente com a velha sociedade, quando "Feira de Santana não passava de agradável alegoria de sutil poema de Francis Jammes".

Confrontando duas imagens da cidade, uma rural e outra urbana, Eurico demonstra as vicissitudes de uma temporalidade marcada por abalos, choques, contradições, rupturas e permanências, que dialeticamente constrói o mundo social. As mudanças pelas quais passou o ambiente urbano feirense geraram o progressivo desaparecimento de traços e elementos característicos de sua aparência mais antiga e, em contrapartida, o nascimento de uma nova realidade constituída de signos culturais que passaram a definir, de um modo geral, a sociedade urbanizada. Tais mudanças são marcadas pela transitoriedade de elementos que integram o aporte cultural do lugar, o que proporciona uma crise ou desestabilização das concepções identitárias. 
A fala do escritor traduz o sentimento de perda ou distanciamento de símbolos socioculturais e identitários que representavam a Feira de Santana antiga. A paisagem rural pouco e pouco se torna urbana. Eurico Alves, que em seus primeiros poemas ressaltava as imagens rústicas de Feira de Santana, as quais, em todo caso, funcionavam como discursos identitários, posto que definiam o lugar, reconheceu na década de 1960 as diferenças notórias que assinalavam a destruição de discursos, representações e práticas que não mais se adequavam ou serviam de referência para identificar a cidade.

Em ambas as Cartas da Serra, Eurico Alves Boaventura deixou entrever as mudanças que redesenhavam o mapa da sua cidade. Mas mostrou-se particularmente apegado à Feira de Santana de outrora e, por isso, insistiu na importância de se resguardar suas memórias e histórias. A segunda carta dá continuidade à primeira com o mesmo propósito de evidenciar a sua terra mater. As mudanças urbanas que desafiavam o olhar do escritor caracterizaram uma nova etapa histórica que paulatinamente alterava cenários da cidade e mexiam com a percepção de seus observadores. Eurico buscou aí criar um ponto de equilíbrio entre o velho e o novo, tradição e modernidade, para que o tempo que se anunciava não pudesse apagar de vez traços originais que definiam o lugar. De tal modo, empenhou-se em fazer conviver no discurso duas temporalidades, passado e presente, pelo menos para que ele próprio não pudesse se sentir um forasteiro em seu próprio solo.

\section{$\operatorname{son}$}

\section{NOTAS}

1 Intelectual e poeta feirense.

2 As duas últimas Cartas da Serra permaneceram inéditas até 2007, quando, junto com as primeiras, além de outros documentos literários do escritor também inéditos, encontrados em seu arquivo pessoal, foram publicadas no livro $A$ paisagem urbana e o homem.

3 Neste artigo serão analisadas apenas as duas primeiras Cartas da Serra, considerando-se a sua repercussão na sociedade feirense por meio do jornal Folha do Norte, em 1960.

4 No fim da década de 1960 a população feirense é quase quatro vezes maior do que era no início da década de 1950. In: CENSO DEMOGRÁFICO DE 1960: Bahia. VII Recenseamento Geral do Brasil: série regional. Rio de Janeiro: IBGE, v.1, n.8, 1960. 137 p.

5 Primeiro nome da atual cidade de Feira de Santana. 
Arquivos de Memória e História: Cartas da Serra, de Eurico Alves

Memory and History Files: Letters from the Mountains, by Eurico Alves

\section{RESUMO}

O escritor feirense Eurico Alves Boaventura é dono de uma vasta produção literária que ao longo da sua vida foi parcialmente levada ao público através de periódicos da Bahia e de outros Estados do Nordeste. No jornal Folha do Norte, que circula em Feira de Santana, sua terra natal, desde 1909, o escritor publicou alguns de seus poemas, sobretudo nas décadas de 1930 e 1940. Anos à frente, em 1960, Eurico editou aí as suas duas primeiras Cartas da Serra, documentos que revelam o enraizamento telúrico e em que se entrelaçam memórias e histórias que dão a conhecer aspectos da fisionomia e do colorido da sua cidade. Este artigo visa apreender as representações de cidade que o escritor estabelece em suas Cartas da Serra, considerando a interface entre história, memória e literatura.

Palavras-chave: Feira de Santana; Jornal Folha do Norte; Memória e história

\section{ABSTRACT}

The writer, Eurico Alves Boaventura, born in Feira de Santana in 1909, had lots of his literary works published in newspapers and magazines from Bahia and from other Northeast States. In Folba do Norte, his town newspaper that is still issued today, he published some of his poems. However, it was in the decades of 1930 and 1940 that most of his works were published. Years ahead, in 1960, he edited his two Cartas da Serra, a work where memories and histories are interwoven in order to unveil aspects related to his colorful hometown. This article deals with the representations of the town the writer presents in his Cartas da Serra taking into account the interface in connection with history, memory and literature.

Key words: Feira de Santana; Folha do Norte newspaper; memory and literature

Recebido em 12/09/2009

Aprovado em 20/07/2009

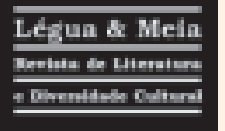

SANTOS, Grazyelle Reis dos. Arquivos de Memória e História: Cartas da Serra, de Eurico Alves. Légua \& meia: Revista de literatura e diversidade cultural. Feira de Santana, UEFS, $\mathrm{n}^{\circ}$ 5, 2009, p. 38-55.

Grazyelle Reis dos Santos é licenciada em História pela Universidade Estadual de Feira de Santana (2005), e tem mestrado em Literatura e Diversidade Cultural, pela mesma Universidade (2008), pesquisa os seguintes temas: literatura e história, jornal e história, teoria e metodologia da história. Já apresentou diversos trabalhos em eventos científicos, em Literatura e História. 